J. Lake Sci. (湖泊科学), 2014, 26(6): 871-878

http://www. jlakes. org. E-mail : jlakes@niglas.ac.cn

(C) 2014 by Journal of Lake Sciences

\title{
福建山仔水库不同季节表层沉积物内源磷负荷分析"
}

\author{
翁 圆 $^{1}$, 苏玉萍 ${ }^{1,3}$, 张玉珍 ${ }^{2 * *}$, 郡 凯 $^{1}$, 詹旋灿 ${ }^{1}$, 刘怡靖 ${ }^{2}$, 姜炳棋 $^{2}$ \\ $(1:$ 福建师范大学环境科学与工程学院,福州 350007$)$ \\ ( 2 : 福建省环境科学研究院, 福州 350013 ) \\ (3:福建师范大学,福建省污染控制与资源循环利用重点实验室,福州 350007)
}

\begin{abstract}
摘 要: 对山仔水库沉积物各形态磷的季节性特征以及夏、冬季磷释放速率进行研究. 结果表明,该水库表层沉积物含有 较丰富的磷, 4 个季节各采样点表层沉积物总磷含量范围为 $(521.23 \pm 7.60) \sim(1255.54 \pm 11.03) \mu \mathrm{g} / \mathrm{g}$, 夏季各采样断面 中总磷含量及各形态磷含量均高于其他季节. 表层沉积物磷以无机磷为主, 且主要赋存形态为铁/铝结合态磷. 活性较大 的铁/铝结合态磷和有机磷占总磷量的 77\% 90\% . 柱状样模拟实验结果表明:夏季溶解性磷释放平均速率范围在 1.66 $2.49 \mathrm{mg} /\left(\mathrm{m}^{2} \cdot \mathrm{d}\right)$, 冬季溶解性磷释放平均速率范围为 $0.69 \sim 1.29 \mathrm{mg} /\left(\mathrm{m}^{2} \cdot \mathrm{d}\right)$, 夏季各采样点表层沉积物磷释放速率 约为冬季的 2 倍. 由于水温分层,夏季沉积物释放的溶解性磷主要滞留在上覆层,但夏季暴雨天气可能导致水温分层破 坏,沉积物释放的溶解性磷对水体将产生重要影响; 冬季由于水温分层破坏导致上、下水层混合, 沉积物释放的溶解性磷 被带到上层, 对上覆水体水质的影响不容忽视.
\end{abstract}

关键词 : 沉积物;磷; 不同季节; 释放速率; 山仔水库;SMT 法

\section{Internal phosphorus loadings and fluxes of surface sediments in four seasons in Shanzi Reservoir}

WENG Yuan ${ }^{1}$, SU Yuping ${ }^{1,3}$, ZHANG Yuzhen ${ }^{2}$, SHAO Kai ${ }^{1}$, ZHAN Xuancan $^{1}$, LIU Yijing ${ }^{2}$ \& JIANG Bingqi ${ }^{2}$ (1: Environmental Science and Engineering College, Fujian Normal University, Fuzhou 350007, P. R. China)

(2: Provincial Academy of Environmental Science, Fuzhou 350013, P. R. China)

(3: Fujian Key Laboratory of Pollution Control and Resource Reuse, College of Environmental Science and Engineering, Fujian Normal University, Fuzhou 350007, P. R. China)

\begin{abstract}
Spatial and temporal variations of different forms of phosphorus of the surface sediments of Shanzi Reservoir were analyzed in four seasons. The Standard Measurement and Test (SMT) and the sediment cores incubation were applied for observing the phosphorus releasing flux in the water-sediment interface. The results showed that the reservoir sediments are rich in phosphorus. The loadings of total phosphorus in surface sediments ranged from $521.23 \pm 7.60 \mu \mathrm{g} / \mathrm{g}$ to $1255.54 \pm 11.03 \mu \mathrm{g} / \mathrm{g}$ in four seasons. The amounts of total phosphorus and other phosphorus forms of all samplings were larger in summer than those in other three seasons. The inorganic phosphorus, the dominant phosphorus form in surface sediments, existed in Fe-bound phosphorus forms. The Fe-bound phosphorus and organic phosphorus occupied for $77 \%$ to $90 \%$ of the total phosphorus. The average releasing rate of dissolved phosphorus ranged from $1.66-2.49 \mathrm{mg} /\left(\mathrm{m}^{2} \cdot \mathrm{d}\right)$ in summer and $0.69-1.29 \mathrm{mg} /\left(\mathrm{m}^{2} \cdot \mathrm{d}\right)$ in winter. The sediment releasing of dissolved phosphorus mainly occurred in the overlying water in summer due to the water temperature stratification. Water temperature stratification may be destroyed if summer rainstorm came and the dissolved phosphorus releasing from the sediments would have a significant impact on the water quality. The water mixed together due to the water temperature stratification disappearing in winter and the dissolved phosphorus was taken to the top water layer, which could greatly affected the overlying water quality. Keywords: Sediments; phosphorus; different seasons; releasing flux; Shanzi Reservoir; SMT
\end{abstract}

* 福建省公益类科研院所专项项目(2011R1004-2)、福建省自然科学基金项目(2014J01154) 和福建师范大学 2014 年 国家级、大学生创新创业训练计划项目联合资助. 2013-10-15 收稿;2014-02-17 收修改稿. 翁圆 (1989 ), 女, 硕士研究生; E-mail : ypanyweng@ 163.com.

** 通信作者;E-mail: zyz9893@163.com. 
水体富营养化是水环境普遍存在的问题, 主要是指在人类活动影响下, 生物所需的氮、磷等营养物质大 量进人水库、河口、湖泊等缓流水体中, 引起水体溶解氧下降、藻类迅速繁殖、鱼类及其他生物大量死亡的现

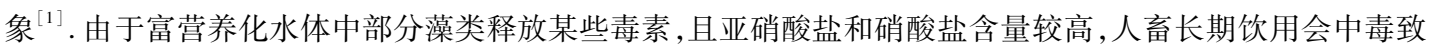
病而引起世界各国高度重视. 特别是饮用水源地富营养化问题, 饮用水源地水质的好坏不仅对当地生产和 生活产生影响,更关系到下游的用水安全 ${ }^{[2]}$.

在引起富营养化的多方面因素中, 养分的过量积累是形成富营养化的最根本原因 ${ }^{[3]}$. 在导致水体富营 养化的营养物质中, 大多数情况下磷是主要限制性因子 ${ }^{[4-5]}$. 磷在水环境中的来源、赋存、迁移和转化等环境 地球化学过程中, 对水生态系统的初级生产力水平具有重要意义 ${ }^{[6]}$. 水库中的沉积物是水生态系统的重要 组成部分, 是营养物质的重要积蓄库, 沉积物既是污染物的 “汇”, 同时在一定条件下也能成为污染物的 “源” ${ }^{[7]}$. 当环境条件改变时, 沉积物在一定程度上起到 “源” 的作用 ${ }^{[8]}$, 主要是沉积物中磷释放进人间隙水, 并通过扩散作用, 在上覆水体中重新循环 ${ }^{[9]}$. 因而在外源磷负荷得到削减和控制的条件下, 内源负荷成为影 响水质的关键所在 ${ }^{[10]}$. 因此, 分析测定沉积物中磷的不同形态、含量及释放速率, 对研究水体的富营养化问 题是很必要的, 也有助于研究水体中磷在沉积物一水界面的迁移转化 ${ }^{[1-12]}$.

目前, 沉积物磷提取采用的 SMT 分级提取法由于具有可操作性强、结果准确等优点受到人们重视 ${ }^{[13-15]}$. 金相灿等 ${ }^{[16]}$ 、王晓丽等 ${ }^{[17]}$ 、赵海超等 ${ }^{[18]}$ 采用 SMT 分级提取法分别对太湖、黄河中上游及洱海表层沉积物磷 的赋存形态变化进行分析. 而测定水库内源营养盐释放中柱状样模拟法可基本上不破坏沉积物形状, 且在 多种控制条件下进行模拟, 因此应用较多 ${ }^{[19]}$. Wu 等 ${ }^{[20]}$ 利用实验室柱状样模拟对河流沉积物进行研究, 发现 沉积物磷释放受微生物影响.

近年来, 福建省有多个主要饮用水源地水库发生程度不等的富营养化. 作为福州市第二饮用水源地的 山仔水库自 2000 年首次暴发蓝藻水华以来, 每年几乎都会出现不同程度的藻类水华,尤其是夏季, 严重影 响水质, 威胁人们日常饮水安全, 危害健康. 沉积物营养盐的时空分布特征已有一定研究 ${ }^{[21-26]}$, 而湖库存在 水质季节性变化 ${ }^{[27]}$, 目前与水体沉积物内源磷季节变化有关的研究开展的相对较少 ${ }^{[28]}$, 因此本文采用 SMT 法对山仔水库不同季节表层沉积物内源磷负荷进行分级提取测定, 同时采用柱状样模拟法比较夏季和冬季 内源磷释放速率, 为探明山仔水库沉积物内源磷负荷及其释放规律, 有效控制山仔水库内源污染, 实现水资 源可持续利用提供科学参考依据.

\section{1 实验设计与方法}

\section{1 研究区域概况和采样点的设置}

敖江是福建省第六大河, 山仔水库位于敖江流域中游, 水库呈长条不规则状分布, 平均水深 30 多米, 调 节库容 $1.06 \times 10^{8} \mathrm{~m}^{3[29]}$, 属中亚热带季风气候区 ${ }^{[30]}$. 山仔水库 1994 年开始蓄水, 1997 年被评为福建省福州 市第二饮用水源, 2003 年正式向福州市供水. 但由于山仔水库建库初期没有彻底清库, 使水库蓄水后大量植 被、腐殖质等有机质腐烂、消解后进人水体, 造成水库内营养盐浓度较高. 同时由于建库后未进行严格的管 理, 生产废水、生活污水、养殖废水、农田和地表径流等各种外源污染输人水库, 进一步增加了水库的营养盐 浓度, 使之呈现富营养化趋势. 2000 年底对山仔水库采取环库截污措施, 对水库周边污染源进行整治, 以此 减少外源污染的输人, 水质短期内出现好转, 但 2002 年后由于水库连续几年出现枯水年份, 水库水流减少, 营养盐浓度再次升高 ${ }^{[31]}$.

根据山仔水库库区的特征, 在便携式全球定位系统 GPS 导航下,于 2011 年 6 月至 2012 年 6 月,在日溪 $\left(26^{\circ} 20^{\prime} 48^{\prime \prime} \mathrm{N}, 119^{\circ} 16^{\prime} 24^{\prime \prime} \mathrm{E}\right)$ 、库心 $\left(26^{\circ} 22^{\prime} 36^{\prime \prime} \mathrm{N}, 119^{\circ} 18^{\prime} 54^{\prime \prime} \mathrm{E}\right)$ 和大坝 $\left(26^{\circ} 20^{\prime} 24^{\prime \prime} \mathrm{N}, 119^{\circ} 19^{\prime} 48^{\prime \prime} \mathrm{E}\right) 3$ 个具有代表 性的断面进行采样 (图 1).

\section{2 沉积物的采集}

在采样点处, 采用奥地利日溪的开闭式不锈钢柱状底泥采样器 (内装有 $\Phi 60 \mathrm{~mm} \times 600 \mathrm{~mm}$ 有机玻璃管) 采集沉积物. 每个点位采集 3 根泥柱. 其中 1 根采集后, 两端用橡皮塞塞紧, 垂直放置, 并用黑色塑料袋蔽光 裹好, 带回实验室, 进行柱状样沉积物磷释放模拟实验; 切割另外 2 根柱状样沉积物 $1 \mathrm{~cm}$ 泥样, 用保鲜膜保 存,排去袋中空气,小心带回实验室. 


\section{3 分析方法}

1.3.1 含水率 利用干湿重之差, 测定沉积物 含水率 ${ }^{[32]}$.

1.3.2 SMT 法提取沉积物各形态磷采用 SMT 法 ${ }^{[14]}$ 分级提取山仔水库不同断面的表层 沉积物 $(0 \sim 1 \mathrm{~cm})$. 将 3 个断面表层沉积物风 干后, 研磨至全部过 100 目篮. 分别用四分法 称取 $0.2 \mathrm{~g}$ 样品, 加 $20 \mathrm{ml} 1 \mathrm{~mol} / \mathrm{L}$ 的 $\mathrm{NaOH}$, 振 荡 $16 \mathrm{~h}$ 后 4000 转 $/ \mathrm{min}$ 离心 $20 \mathrm{~min}$, 取 $10 \mathrm{ml}$ 上 清液, 加人 $4 \mathrm{ml} 3.5 \mathrm{~mol} / \mathrm{L} \mathrm{HCl}$, 静置 $16 \mathrm{~h}$ 后离 心, 得到铁/铝结合态磷; $1 \mathrm{~mol} / \mathrm{L} \mathrm{NaOH}$ 提取 后的残渣加人 $20 \mathrm{ml} 1 \mathrm{~mol} / \mathrm{L} \mathrm{HCl}$, 振荡 $16 \mathrm{~h}$ 后 提取钙结合态磷; 称取 $0.2 \mathrm{~g}$ 样品, 加 $20 \mathrm{ml}$ $1 \mathrm{~mol} / \mathrm{L} \mathrm{HCl}$, 振荡 $16 \mathrm{~h}$ 后提取无机磷; 残渣用 去离子水洗涤 2 次, 于 $450^{\circ} \mathrm{C}$ 马弗炉中灰化 $3 \mathrm{~h}$, 加 $20 \mathrm{ml} 1 \mathrm{~mol} / \mathrm{L} \mathrm{HCl}$, 振荡 $16 \mathrm{~h}$ 后提取有 机磷; 称取 $0.2 \mathrm{~g}$ 样品, 于 $450^{\circ} \mathrm{C}$ 马弗炉中灰化 $3 \mathrm{~h}$, 加 $20 \mathrm{ml} 3.5 \mathrm{~mol} / \mathrm{L} \mathrm{HCl}$, 振荡 $16 \mathrm{~h}$ 后提取 总磷. SMT 法提取的各形态磷, 采用钼锑抗分 光法进行测定 ${ }^{[33]}$. 每个样品做 3 个平行样, 数 据用平均值 \pm 标准偏差表示.

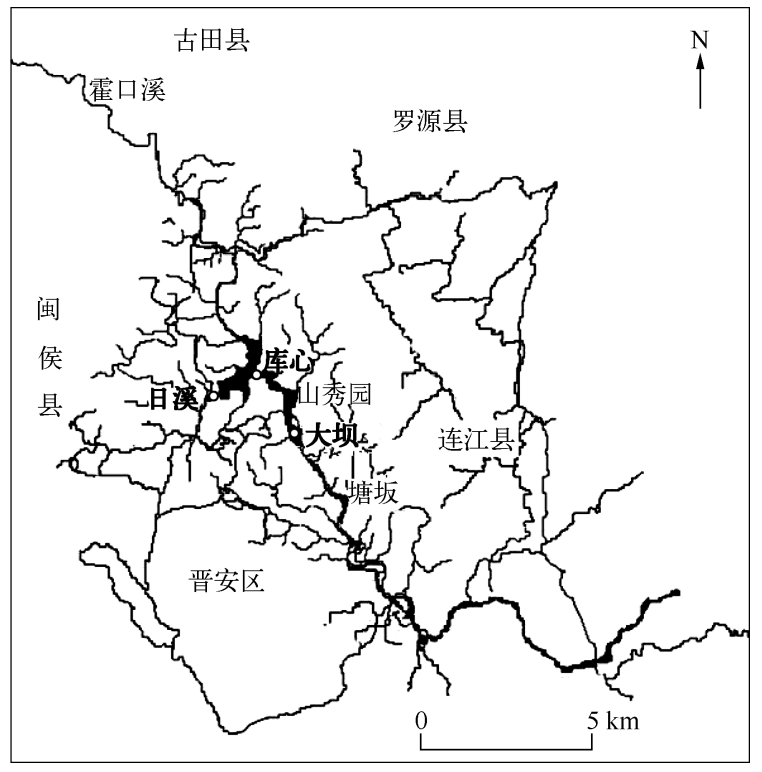

图 1 山仔水库地理位置和采样点分布

Fig. 1 Geographical location and distribution of sampling sections in Shanzi Reservoir

\section{4 柱状样磷释放速率模拟实验}

本实验设置 3 个变量: 温度、溶解氧和培养用水. 温度设置为 $30^{\circ} \mathrm{C}$ (夏季) 和 $10^{\circ} \mathrm{C}$ (冬季), 溶解氧设置为 好氧 (冬季) 和厌氧 (夏季). 在 $10^{\circ} \mathrm{C}$ 条件下, 日溪、库心、大坝断面分别加人蒸馏水 $500 \mathrm{ml}$ 和原采样点水样 $500 \mathrm{ml}$ 培养, 并充人氧气 $30 \mathrm{~min}$, 以模拟冬季水库实际情况, 测定冬季水库沉积物的磷释放速率. 而在 $30^{\circ} \mathrm{C}$ 条件下, 日溪、库心、大坝断面分别加入蒸馏水 $500 \mathrm{ml}$ 和原采样点水样 $500 \mathrm{ml}$ 培养, 并充人氮气 $30 \mathrm{~min}$, 以模 拟夏季水库情况.

在室内将柱状样中上层水体用虹吸法抽去,再用虹吸法沿壁小心滴注经 $0.45 \mu \mathrm{m}$ 纤维滤膜过滤的原采 样点水样, 至液面高度距沉积物表面 $20 \mathrm{~cm}$ 处停止 (此时水柱体积为 $500.00 \mathrm{ml}$ ), 标注刻度. 将柱状沉积物 样品垂直放人生化恒温培养箱中避光培养 ${ }^{[33]}$. 此后每隔 $1 \mathrm{~d}$ 用移液管于水柱中段取样, 每次取样体积为 $100 \mathrm{ml}$, 测定水样溶解性磷浓度, 直到释放平衡. 同时用 $100 \mathrm{ml}$ 原采样点过滤水样补充培养管至刻度. 营养盐 的释放速率按公式 (1) 进行计算 ${ }^{[34]}$ :

$$
R=\left[V\left(C_{n}-C_{0}\right)+\sum_{j=1}^{n} V_{j-1}\left(C_{j-1}-C_{\mathrm{a}}\right)\right] / S \cdot t
$$

式中, $R$ 为释放速率 $\left(\mathrm{mg} /\left(\mathrm{m}^{2} \cdot \mathrm{d}\right)\right), V$ 为柱中上覆水体积 $(\mathrm{L}), C_{n} 、 C_{0} 、 C_{j-1}$ 分别为第 $n$ 次、 0 次 (即初始) 和 $j-1$ 次采样时某物质含量 $(\mathrm{mg} / \mathrm{L}), C_{\mathrm{a}}$ 为添加的原水中某物质含量 $(\mathrm{mg} / \mathrm{L}), V_{j-1}$ 为第 $j-1$ 次采样体积 $(\mathrm{L}), S$ 为柱状沉积物中水一沉积物界面的面积 $\left(\mathrm{m}^{2}\right), t$ 为释放时间 $(\mathrm{d})$.

\section{2 结果与讨论}

\section{1 山仔水库不同季节表层沉积物各形态磷含量}

山仔水库不同季节表层沉积物中总磷含量变化范围很大,具有季节性波动特征 (表 1 ), 波动幅度与水库 营养水平相关. 春季 ( 3 月) 表层沉积物总磷含量为 $(658.31 \pm 7.92) \sim(1028.65 \pm 10.75) \mu \mathrm{g} / \mathrm{g}$, 夏季 $(6$ 月) 表层沉积物总磷含量为 $(715.26 \pm 9.69) \sim(1255.54 \pm 11.03) \mu \mathrm{g} / \mathrm{g}$, 秋季 $(9$ 月) 表层沉积物总磷含量为 (580.27 \pm 12.09$) \sim(976.92 \pm 10.32) \mu \mathrm{g} / \mathrm{g}$, 冬季 (12 月) 表层沉积物总磷含量为 $(521.23 \pm 7.60) \sim(724.65 \pm$ 
8.18) $\mu \mathrm{g} / \mathrm{g}$. 其中, 夏季各采样点中总磷含量均高于其他季节. 一方面可能是由于夏季雨量大, 雨水冲刷作用 使地表含磷物质被带人水库中, 沉积在水库底部, 成为沉积物的 “源”. 另一方面, 水体中内源磷负荷与藻类 群落结构、丰度具有相互作用. 磷源是藻类水华暴发的重要限制因素 ${ }^{[35]}$, 对藻类生长具有决定性作用. 但当 外源输人一定的情况下, 生物群落结构变化能显著改变内源磷负荷 ${ }^{\left[{ }^{[} 6\right]}$. 春、夏季通常是水生植物萌发、生长 和繁殖的季节, 特别是夏季, 藻类生长最为旺盛 ${ }^{[37]}$, 藻类的大量繁殖, 增加了对营养盐的需求, 进而加剧了沉 积物磷释放. 冬季温度降低, 有机物分解, 沉积物磷释放作用减少 ${ }^{[38]}$, 同时水生植物生长减弱, 对营养盐需求 减小, 导致沉积物作为 “源” 的功能下降 ${ }^{[39]}$. 同一季节的空间分布规律是沿日溪 $\rightarrow$ 库心 $\rightarrow$ 大坝各形态磷含量 逐渐增加, 反映了营养物随着水流在沉积物中逐渐积累. 这可能是因为山仔水库库底主要为盆地形态, 水深 递增, 因而水流流速沿上游向下游逐渐减小, 进而对外源污染扩散造成一定影响, 更加有利于磷的沉积.

表 $12011-2012$ 年山仔水库表层沉积物中各形态磷含量

Tab. 1 The content of different forms of phosphorus in surface sediments of Shanzi Reservoir from 2011 to 2012

\begin{tabular}{|c|c|c|c|c|c|c|}
\hline 时间 & 断面 & 总磷/( $\mu \mathrm{g} / \mathrm{g})$ & 铁/铝结合态磷/（ $\mu \mathrm{g} / \mathrm{g}$ ) & 钙结合态磷/ $(\mu \mathrm{g} / \mathrm{g})$ & 无机磷/ ( $\mu \mathrm{g} / \mathrm{g})$ & 有机磷/ $(\mu \mathrm{g} / \mathrm{g})$ \\
\hline \multirow[t]{3}{*}{2011 年夏季 } & 日溪 & $715.26 \pm 9.69$ & $391.64 \pm 7.06$ & $117.33 \pm 11.03$ & $419.38 \pm 10.38$ & $249.40 \pm 9.14$ \\
\hline & 库心 & $935.35 \pm 12.28$ & $517.38 \pm 8.56$ & $126.16 \pm 6.96$ & $786.48 \pm 12.26$ & $265.56 \pm 10.07$ \\
\hline & 大坝 & $1255.54 \pm 11.03$ & $676.01 \pm 10.73$ & $197.14 \pm 9.29$ & $906.43 \pm 9.04$ & $358.35 \pm 9.23$ \\
\hline \multirow[t]{3}{*}{2011 年秋季 } & 日溪 & $580.27 \pm 12.09$ & $317.08 \pm 8.83$ & $97.92 \pm 7.92$ & $377.75 \pm 10.65$ & $181.56 \pm 7.13$ \\
\hline & 库心 & $685.80 \pm 12.26$ & $388.64 \pm 10.02$ & $115.26 \pm 9.39$ & $467.82 \pm 18.88$ & $227.25 \pm 8.41$ \\
\hline & 大坝 & $976.92 \pm 10.32$ & $466.25 \pm 9.18$ & $141.87 \pm 6.80$ & $682.75 \pm 17.05$ & $267.62 \pm 9.28$ \\
\hline \multirow[t]{3}{*}{2011 年冬季 } & 日溪 & $521.23 \pm 7.60$ & $266.16 \pm 6.62$ & $86.15 \pm 10.64$ & $362.70 \pm 6.54$ & $149.03 \pm 6.10$ \\
\hline & 库心 & $622.94 \pm 7.89$ & $331.09 \pm 8.32$ & $98.75 \pm 9.67$ & $435.79 \pm 9.45$ & $177.09 \pm 7.46$ \\
\hline & 大坝 & $724.65 \pm 8.18$ & $396.02 \pm 10.02$ & $111.35 \pm 8.70$ & $508.87 \pm 12.45$ & $205.14 \pm 8.82$ \\
\hline \multirow[t]{3}{*}{2012 年春季 } & 日溪 & $658.31 \pm 7.92$ & $304.99 \pm 6.07$ & $93.48 \pm 4.59$ & $358.33 \pm 10.10$ & $203.59 \pm 7.95$ \\
\hline & 库心 & $938.05 \pm 4.60$ & $435.59 \pm 10.79$ & $105.71 \pm 5.05$ & $692.48 \pm 10.15$ & $228.25 \pm 10.34$ \\
\hline & 大坝 & $1028.65 \pm 10.75$ & $548.54 \pm 7.81$ & $113.01 \pm 5.74$ & $897.60 \pm 5.95$ & $297.59 \pm 12.36$ \\
\hline \multirow[t]{3}{*}{2012 年夏季 } & 日溪 & $812.00 \pm 6.59$ & $430.90 \pm 10.76$ & $168.58 \pm 3.76$ & $622.52 \pm 7.18$ & $208.11 \pm 7.87$ \\
\hline & 库心 & $830.27 \pm 6.32$ & $486.51 \pm 7.33$ & $189.68 \pm 2.70$ & $703.99 \pm 10.64$ & $244.09 \pm 4.60$ \\
\hline & 大坝 & $1206.25 \pm 5.64$ & $899.97 \pm 5.41$ & $121.59 \pm 3.34$ & $1008.50 \pm 6.98$ & $302.00 \pm 10.70$ \\
\hline
\end{tabular}

2011-2012 年山仔水库各季节表层沉积物均以无机磷为主, 且无机磷含量远远大于有机磷含量, 占总 磷含量的 $58 \% \sim 88 \%$, 同时无机磷与总磷含量变化趋势相同 (表 1). 此外, 夏季各采样点无机磷含量均明显 高于同一采样点其他季节的含量, 且以冬季含量最低. 由于夏季温度普遍较高, 光照较强, 微生物活性较强, 有机质矿化加剧 ${ }^{[40-41]}$, 进而促进磷的释放. 同时夏季水温分层, 沉积物释放的溶解性磷主要滞留在上覆层, 而 在水温分层受到破坏的冬季, 上下水层混合, 沉积物释放的溶解性磷则被带到上层, 对水体表层水质产生重要 影响, 因此冬季的影响也不容忽视. 沉积物中无机磷主要赋存形态为铁/铝结合态磷, 占无机磷含量的 $61 \%$ $94 \%$. 这可能是由于沉积物中的铁/铝结合态磷不稳定, 易被解析, 会随环境条件而变. 当氧化还原电位降低 时, $\mathrm{Fe}^{3+}$ 被还原为 $\mathrm{Fe}^{2+}$ 并溶解, 促进与 $\mathrm{Fe}^{3+}$ 结合的铁/铝结合态磷的释放. 此外, 铁磷是藻类可充分利用的磷 形态 ${ }^{[40]}$, 大量铁/铝结合态磷存在, 水体中充足的营养盐与有利的外界环境相结合更利于藻类大量生长, 因 而夏季频繁暴发藻类水华, 藻类旺盛生长的同时也有利于铁/铝结合态磷释放进人上覆水. 而在沉积物内源 磷负荷中, 钻磷所占百分含量较小, 可能是由于钲磷是沉积物磷中相对稳定的组分, 对磷在沉积物中长期埋 藏具有很大的贡献 ${ }^{[42]}$, 通常不易释放, 被认为是生物难利用磷 ${ }^{[43]}$, 通常被看作永久性磷汇, 在弱酸条件下才 会有少量的释放 ${ }^{[44]}$. 有机磷含量夏季高于其他季节, 冬季含量最低. 主要由于有机磷同样是沉积物中惰性较 大的赋存形态, 被认为只有部分可转化为生物可利用磷. 有机磷存在于沉积物中各种动植物残体和腐殖质 中, 不易被藻类等水生植物吸收 ${ }^{[45]}$, 只能在微生物矿化作用下转化成无机磷 ${ }^{[46]}, \operatorname{Rydin}^{[47]}$ 的研究结果表明, $50 \% \sim 60 \%$ 的有机磷可在微生物作用下转化为生物可利用磷释放到水体中, 使水体营养水平增加, 对富营养 化有一定的贡献 ${ }^{[48]}$. 但由于有机磷含量与人类活动有关 ${ }^{[24]}$, 其损耗通常通过农业面源污染得到补充. 在各 
形态磷中, 有机磷和铁/铝结合态磷活性较大, 因此山仔水库具有较大释磷潜能, 同时能够为藻类生长提供 充足的可利用磷 ${ }^{[43]}$.

选取本研究中 2011 年 12 月与课题组 2004 年 1 月总磷含量进行比较 (图 2). 总体上,沉积物总 磷含量沿日溪 $\rightarrow$ 库心 $\rightarrow$ 大坝逐渐增加, 说明营养 物质随水流方向逐渐积累. 同时, 2011 年 12 月各 采样点表层沉积物总磷含量均显著高于 2004 年 1 月 $(P<0.01)$, 增加量为 $3.77 \% \sim 20.04 \%$, 表明随 着时间的推移,外源污染物逐渐在水库底部沉积, 从而使得沉积物总磷含量随着年份增加而增大.

\section{2 国内部分水库、湖泊沉积物磷含量比较研究}

侯翠荣 ${ }^{[49]}$ 通过研究发现水库底部存在能够 提供丰富营养物质 (如内源磷负荷) 的底泥是水库 形成活性反应带的必要条件. 水库中的沉积物营 养盐负荷来源于上覆水体营养盐的沉降积累. 山 仔水库库龄虽不长, 建库蓄水至今不足 20 年, 但 从表 2 中可以看出, 目前山仔水库各季节沉积物 磷含量处在中上水平, 并且在山仔水库表层沉积 物中所占比例较大的铁/铝结合态磷、有机磷均为 具有较大 “活性” 的磷形态, 说明山仔水库具有相 当的释磷潜能. 同时由于山仔水库位于亚热带季 风气候区的福建省福州市, 夏季炎热、冬季温暖. 一方面,夏季较高的水温使得水体中微生物活性 加强, 单位时间内耗氧量增加, 而空气中通过扩散 作用溶解在水中的氧气无法补偿消耗, 导致水库 底部形成厌氧区; 随水温升高, 厌氧层厚度逐渐增 加, 从而加速沉积物可溶性磷的释放 ${ }^{[50]}$; 另一方 面, 水体中微生物的活动可能使表层沉积物中的 有机磷转变为无机态磷酸盐, 从而向上覆水中释 放. 此外,由于夏季雨水冲刷作用,外源污染负荷

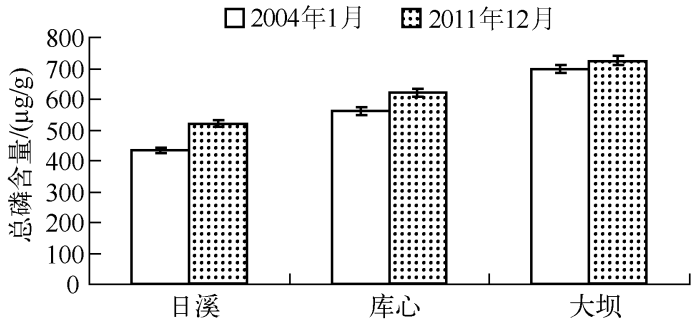

图 2 山仔水库 2011 年 12 月与 2004 年 1 月 表层沉积物总磷含量

Fig. 2 The total phosphorus content in the surface sediments of Shanzi Reservoir in December of 2011 and January of 2004

表 2 国内部分水库和湖泊沉积物磷含量比较

Tab. 2 The comparison of the content of phosphorus in the sediments in part of domestic reservoirs and lakes

\begin{tabular}{ccl}
\hline 湖库 & 研究时间 & 磷含量 $/(\mu \mathrm{g} / \mathrm{g})$ \\
\hline 密云水库 $^{[51]}$ & 4 月 & $760.00 \sim 910.00$ \\
山仔水库 $^{[52]}$ & 1 月 & $400.00 \sim 700.00$ \\
洋河水库 $^{[53]}$ & 3 月 & $311.99 \sim 817.64$ \\
长寿湖 $^{[54]}$ & 4 月 & $495.86 \sim 783.71$ \\
于桥水库 $^{[55]}$ & 5 月 & $354.00 \sim 581.00$ \\
峡水库 $^{[56]}$ & 6 月 & $361.60 \sim 1033.50$ \\
百花湖 $^{[57]}$ & 9 月 & $221.00 \sim 637.00$ \\
山仔水库(本研究) & 3 月 & $658.31 \sim 1028.70$ \\
& 6 月 & $715.26 \sim 1255.50$ \\
& 9 月 & $580.27 \sim 976.92$ \\
& 12 月 & $521.23 \sim 724.65$ \\
\hline
\end{tabular}
进人库区, 并随时间积累, 加大了沉积物中营养负荷. 因此,在通过截污、截流等措施控制山仔水库外源输人 的同时,也应重视沉积物的内源负荷,因地制宜地提出有效措施来控制水华的发生.

山仔水库表层沉积物中总磷与无机磷、有机磷之间显著相关,且与无机磷相关性最高 $(P<0.01)$, 无机 磷与铁/铝结合态磷之间存在极显著正相关 $(P<0.01)$. 铁/铝结合态磷是沉积物内源磷负荷的最主要组成 成分, 总磷空间分布很大程度受其控制与影响. 同时, 铁/铝结合态磷为湖泊沉积物一水界面迁移转化中最为 重要的磷形态, 还原条件下很容易释放到间隙水和表层上覆水中, 是具有释放潜力的一部分磷 ${ }^{[37]}$. 间隙水与 表层沉积物铁/铝结合态磷、有机磷呈极显著相关 $(P<0.01)$, 表明间隙水中磷主要来自铁/铝结合态磷释放 及有机磷分解, 同时说明山仔水库中铁/铝结合态磷和有机磷具有较大释放潜能. 随着沉积物一水界面温度 的升高, 微生物代谢作用增强, 有机磷被分解成可溶性的磷酸盐, 释放到间隙水中,随着沉积物一水界面的厌 氧环境逐渐形成, 沉积物中铝/铁磷释放作用加强 ${ }^{[58]}$.

\section{3 水库夏、冬季表层沉积物磷释放速率}

通过柱状样模拟夏、冬季不同断面沉积物上覆水中溶解性磷浓度变化可以看出,各采样点溶解性磷浓度 变化均为先增加,到达一峰值后又下降, 反映了沉积物一水界面正磷酸盐的吸附和解析动态. 不同季节、不同断 面沉积物蒸馏水培养均在 $96 \mathrm{~h}$ 达到动态平衡,此后溶解性磷浓度基本维持在平衡点, 略有波动( 图 3 ). 


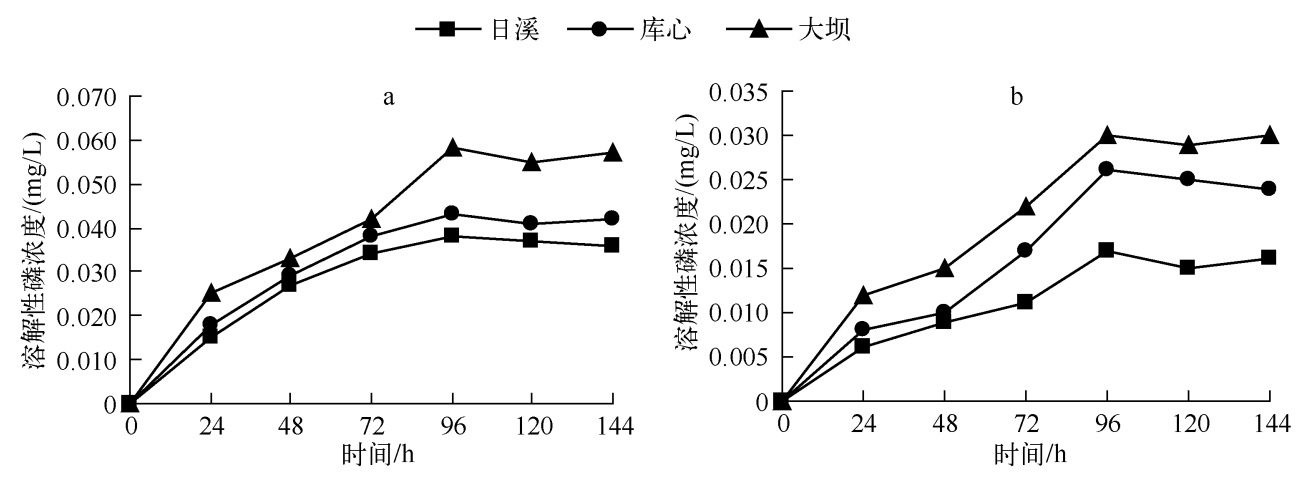

图 3 夏季 (a) 和冬季 (b) 不同断面蒸馏水培养上覆水中溶解性磷浓度的变化

Fig. 3 The dynamic concentration of dissolved phosphorus in the overlying water with distillated water of different sections in summer(a) and winter(b) under the controlling simulation conditions

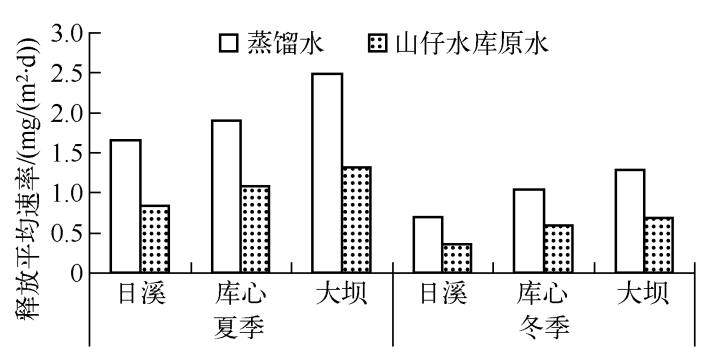

图 4 实验室培养法测算的溶解性磷释放平均速率

Fig. 4 The average releasing rate of dissolved phosphorus calculated by laboratory culture

柱状样模拟条件下夏季各个断面上覆水中溶 解性磷释放速率均高于同一断面冬季上覆水中溶 解性磷释放速率 (图 4). 实验室模拟实验结果与 水库底部水体水质测定结果基本一致, 表明水库 底部水质超标是由戻氧条件下沉积物中污染物的 释放所致. 夏季溶解性磷释放平均速率范围为 $1.66 \sim 2.49 \mathrm{mg} /\left(\mathrm{m}^{2} \cdot \mathrm{d}\right)$, 冬季溶解性磷释放平 均速率范围为 $0.69 \sim 1.29 \mathrm{mg} /\left(\mathrm{m}^{2} \cdot \mathrm{d}\right)$. 这可能 是由于夏季普遍高温, 微生物活性增强, 生物作用 强烈, 利于微生物新陈代谢, 使沉积物作为营养盐 的源不断向上覆水体提供可溶性营养盐, 同时, 表 层沉积物中生物可利用磷的减少, 又进一步使磷

释放过程加剧 ${ }^{[39]}$. 水体分层是深水水库中出现的一种常见自然现象, 常发生在温差效应足以克服当地自然 混合进程的夏、冬季 ${ }^{[59]}$. 当水体分层后, 底层水体由于氧气得不到补充而使溶解氧逐步减少, 同时生物的呼 吸作用和底泥中大量还原性物质的氧化作用造成溶解氧的进一步消耗, 从而使底层水体处于缺氧或戻氧状 态 ${ }^{[60]}$. 厌氧状态下, 沉积物中的聚磷菌快速释磷 ${ }^{[61-62]}$, 加快沉积物磷释放. 由于水温分层, 夏季沉积物释放的 溶解性磷主要滞留在上覆层. 而春、秋季, 翻库作用下大量营养物质从底层被输送到表层 ${ }^{[21]}$, 会造成整个水 库水质污染, 导致水库水质周期性恶化, 同时由于表层水体获得足够的营养盐而促进水体富营养化, 导致水 库水质进一步恶化 ${ }^{[21]}$,从而进一步说明控制水库内源污染、改善底部水体环境极为重要.

此外,2011 年山仔水库夏、冬季原水培养的沉积物磷释放速率与蒸馏水培养的沉积物磷释放速率存在 显著差异 (图 4). 夏、冬季经蒸馏水培养的沉积物磷释放速率显著高于同一季节山仔水库原水培养的, 且释 放速率约为同季山仔水库原水培养的 $1.75 \sim 1.98$ 倍. 这可能是由于沉积物向上覆水中释放磷主要是通过浓 度梯度扩散力及微生物协同作用, 蒸馏水培养中主要受浓度梯度扩散作用. 夏、冬季 3 个断面溶解性磷释放 速率在空间分布上具有一定规律性, 即释放速率沿日溪 $\rightarrow$ 库心 $\rightarrow$ 大坝依次增加, 这与各采样点总磷含量分 布规律一致. 这可能是由于沉积物中各形态磷含量是释放到上覆水的基础, 因此磷含量高的点位释放速率 也高.

\section{3 结论}

1) 山仔水库 4 个季节各采样点表层沉积物总磷含量范围为 $(521.23 \pm 7.60) \sim(1255.54 \pm$ $11.03) \mu \mathrm{g} / \mathrm{g}$, 其中夏季各采样点总磷含量均高于其他季节, 且同一季节总磷含量空间分布规律是沿日溪 $\rightarrow$ 
库心 $\rightarrow$ 大坝逐渐增加, 表明营养物质随水流方向逐渐积累沉积. 不同季节表层沉积物总磷含量均以无机磷 为主, 活性较大的铁/铝结合态磷和有机磷占总磷的 $77 \%$ 90\% , 而有机磷能够在微生物矿化作用下转化为 无机磷并释放到水体中,提高水体营养水平,对富营养化有重要贡献.

2) 山仔水库夏季溶解性磷释放平均速率范围为 $1.66 \sim 2.49 \mathrm{mg} /\left(\mathrm{m}^{2} \cdot \mathrm{d}\right)$, 冬季溶解性磷释放平均速率 范围为 $0.69 \sim 1.29 \mathrm{mg} /\left(\mathrm{m}^{2} \cdot \mathrm{d}\right)$. 同一断面, 夏季各采样点表层沉积物磷释放速率均高于冬季, 约为冬季释 放速率的 2 倍. 由于水温分层, 夏季沉积物释放的溶解性磷主要滞留在上覆层, 但夏季暴雨天气可能导致水 温分层破坏, 沉积物释放的溶解性磷对水体将产生重要影响, 冬季由于水温分层破坏导致上下水层混合,沉 积物释放的溶解性磷被带到上层,对上覆水体水质的影响不容忽视.

\section{4 参考文献}

[1] 戴树桂. 环境化学:第 2 版. 北京:高等教育出版社,2006.

[2] 藏常娟, 黄岁樑, 吴 敏等. 环境因子对鱼垀中磷释放影响的实验研究. 水资源与水工程学报, 2011,22(2):10-14.

[ 3 ] 韩耀全,周 解. 龙滩水库与天生桥水库水体富营养化类比研究报告.广西水产科技,2011,(1):31-43.

[ 4 ] 康丽娟,孙从军,李小平. 淀山湖沉积物磷分布特征. 环境科学学报,2012,32(1): 190-196.

[ 5 ] 黄廷林,延 霜,柴蓓蓓等. 水源水库沉积物磷形态分布及其释放特征. 天津大学学报, 2011, 44 (7) :607-612.

[ 6 ] 王雨春,万国江, 黄荣贵等. 湖泊现代化沉积物中磷的地球化学作用及环境效应. 重庆环境科学, 2000,22(4): $39-41$.

[ 7 ] Jeppesen E, Sondergaard M, Jensen JP et al. Lake responses to reduced nutrient loading-an analysis of contemporary longterm data from 35 case studies. Freshwater Biology, 2005, 50(10): 1747-1771.

[ 8 ] 郭海涛,张进忠,魏世强等. 长寿湖沉积物中磷形态的季节变化特征. 环境科学, 2011,32 (7) : 1994-1999.

[ 9 ] Li QM, Zhang W, Wang XX et al. Phosphorus in interstitial water induced by redox potential in sediment of Dianchi Lake, China. Pedosphere, 2007, 17(6): 739-746.

[10］安文超,张书武,李小明等. 南阳湖和微山湖表层沉积物磷负荷及吸附、释放特性. 南水北调与水利科技, 2012,10 (6) :61-64.

[11 ] Peng JF, Wang BZ, Song YH et al. Adsorption and release of phosphorus in the surface sediment of a wastewater stabilization pond. Ecological Engineering, 2007, 31(2) : 92-97.

[12] Ruttenberg KC. Development of a sequential extraction method for different forms of phosphorus in marine sediments. Limnology and Oceanography, 1992, 37 (7): 1460-1482.

[13] 朱广伟,秦伯强. 沉积物中磷形态的化学连续提取法应用研究. 农业环境科学学报, 2003,22(3) : 349-352.

[14] Ruban V, López-Sánchez JF, Pardo P et al. Harmonized protocol and certified reference material for the determination of extractable contents of phosphorus in freshwater sediments - A synthesis of recent works. Fresenius' Journal of Analytical Chemistry, 2001, 370: 224-228.

[15] Ruban V, Brigault S, Demare D et al. An investigations of the origin and mobility of phosphorus in freshwater sediments from Bort-Les-Orgues Reservoir, France. Journal of Environmental Monitoring, 1999, (4) : 403-407.

[16] 金相灿, 王圣瑞, 庞 燕. 太湖沉积物磷形态及 $\mathrm{pH}$ 值对磷释放的影响. 中国环境科学, 2004,24(6): 701-711.

[17］王晓丽,包华影. 黄河上中游表层沉积物磷的赋存形态特征. 生态环境学报,2010,19(6): 1358-1362.

[18］赵海超,王圣瑞,焦立新等. 洱海沉积物中不同形态磷的时空分布特征. 环境科学研究, 2013,26(3):227-234.

[19］范成新,张 路,杨龙元等. 湖泊沉积物氮磷内源负荷模拟. 海洋与湖沼, 2002,33(4) :370-378.

[20 ] Wu QH, Zhang RD, Huang S et al. Effects of bacteria on nitrogen and phosphorus release from river sediment. Journal of Environmental Sciences, 2008,(20): 404-412.

[21］黄廷林,章武首,柴蓓䔒. 大水深水库内源污染特征及控制技术. 环境污染与防治, 2010,32(3): 1-4.

[22] 夏品华,林 陶,李存雄等. 贵州高原红枫湖水库季节性分层的水环境质量响应. 中国环境科学, 2011,31 (9): 1477-1485.

[23] 安文超,张书武,和 慧等. 南四湖及主要人湖河流河口区表层沉积物磷的形态与分布特征研究. 环境科学学报, 2012,2 (4) : 895-901.

[24] 汪艳雯,岳钦艳,刘 庆等. 山东省南四湖底泥中磷的形态分布特征. 中国环境科学, 2009,29(2):125-129.

[25] 周 来,冯启言,王 华等. 南四湖表层底泥磷的化学形态及其释放规律. 环境科学与技术, 2007,30 (6) :37-39.

[26] 杨丽原, 沈 吉,刘恩峰等. 南四湖现代沉积物中营养元素分布特征. 湖泊科学, 2007,19(4):390-396.

[27] 黄廷林,秦昌海,李 璇. 石砭峪水库氮、磷营养盐季节变化及其收支分析. 西安建筑科技大学学报: 自然科学版, 
2013,45 (1) : 111-116.

[28］邓焕广,张 菊. 东昌湖水体富营养化评价及 N、P 平衡研究. 环境科学与管理,2008,33(8):178-180.

[29］刘用凯. 山仔水库水质富营养化防治对策. 福建环境,2001,18(1):14-16.

[30］陈文花,张江山, 曾 雨等. 福州山仔水库底泥磷释放规律的研究. 云南环境科学, 2006,25(2) :35-37.

[31] 翁笑艳,杨 芳,林志鹏. 福建省山仔水库水质现状及演变趋势分析. 环境科学与管理,2011,36(8):114-121.

[32］ 杜 森,高祥照.土壤分析技术规范:第 2 版. 北京:中国农业出版社,2006.

[33] 金相灿. 湖泊富营养化调查规范:第 2 版. 北京: 中国环境科学出版社,1990:164-188.

[34] 王建军, 沈 吉, 张 路等. 云南滇池和抚仙湖沉积物一水界面营养盐通量及氧气对其的影响. 湖泊科学, 2010,22 (5) :640-648.

[35] 秦伯强. 太湖水环境面临的主要问题,研究动态与初步进展. 湖泊科学, 1998,10(4):1-9.

[36] 谢 平. 浅水湖泊内源磷负荷季节变化的生物驱动机制. 中国科学:D 辑: 地球科学, 2005,35 (增刊 II ): 11-23.

[37] 李 博. 生态学. 北京:高等教育出版社,2000.

[38] 潘建明,扈传昱,陈建芳等. 南海海域海水中各形态磷的化学分布特征. 海洋学报,2004,26(1):40-47.

[39] 徐玉慧. 太湖表层沉积物中氮磷生物可利用性的季节性变化 [学位论文]. 长春: 吉林大学,2006.

[40］王 佩,卢少勇,王殿武等. 太湖湖滨带底泥氮、磷、有机质分布与污染评价. 中国环境科学,2012,32(4):703-709.

[41] 陈如海,詹良通, 陈云敏等. 西溪湿地底泥氮、磷和有机质含量坚向分布规律. 中国环境科学, 2010,30(4): 493-498.

[42］黎颖治,夏北成. 湖泊沉积物内部因素对沉积物一水界面磷交换的影响. 土壤通报,2006,37(5):1017-1021.

[43] 刘 蹈. 滇池沉积物磷污染与有机磷组成特征研究 [学位论文]. 南京:东南大学,2008.

[44] 刘 蹈,齐国辅,高海鹰. 滇池沉积物磷形态的水平分布特征. 安全与环境工程,2010,17(6):26-29.

[45] 李 宝, 王志奇, 王千锁等. 山东省南四湖夏冬季沉积物及间隙水中磷分布特征及其相关性. 应用生态学报, 2013, 24 (6) 6 :1699-1706.

[46] 李英军, 熊善高, 魏自民等. 镜泊湖沉积物中有机磷的矿化特性研究. 东北农业大学学报, 2011,42(8):112-116.

[47] Rydin E. Potentially mobile phosphorus in Lake Erken sediment. Water Research, 2000, 34(7) : 2037-2042.

[48] 吴丰昌,金相灿,张润宇等. 论有机氮磷在湖泊水环境中的作用和重要性. 湖泊科学,2010,22(1):1-7.

[49] 侯翠荣. 高藻高有机污染水源水处理技术研究 [学位论文]. 济南:山东大学, 2008.

[50] 何 芳, 李富生, 王立国. 浅水型水库活性区沉积物氮磷释放特征. 中南大学学报: 自然科学版, 2012, $43(2)$ : 783-788.

[51] 刘 汶,刘晓端,徐 清等. 密云水库沉积物中磷的形态和分布特征. 岩矿测试,2003,22(2):81-85.

[52］苏玉萍,郑达贤,林婉珍等. 福建省富营养化水库沉积物磷形态及对水体的贡献. 湖泊科学, 2005,17(4):311-316.

[53] 张丽媛. 洋河水库集水区氮磷污染特征及流域面源污染负荷估算研究 [学位论文]. 呼和浩特: 内蒙古农业大 学, 2010 .

[54] 胡鹏飞,何太蓉, 金慧芳等. 长寿湖表层沉积物中磷的赋存形态及生物有效性分析. 水生态学杂志, 2012, 33(1): 9-13.

[55] 朱兴旺, 刘光逊, 梁丽君等. 天津于桥水库沉积物理化特征及磷赋存形态研究. 农业环境科学学报, 2010,29(1): 168-173.

[56] 张 琳,毕永红,胡征宇等.三峡水库湖北段沉积物磷形态及其分布特征. 环境科学与技术,2011,32(6):6-9.

[57] 方志青, 李存雄, 张明时等. 百花湖、阿哈水库底泥及营养盐蓄积量的估算. 贵州师范大学学报: 自然科学版,2009, 27 (4):30-33.

[58] 苏玉萍,林 佳,何 灵等. 福建省山仔水库沉积物磷对水体磷浓度贡献的估算. 湖泊科学, 2008,20(6) :748-754.

[59] Holt J, Umlauf L. Modelling the tidal mixing fronts and seasonal stratification of the Northwest European Continental shelf. Continental Shelf Research, 2008, 28(7): 887-903.

[60] Sahoo GB, Luketina D. Modeling of bubble plume design and oxygen transfer for reservoir restoration. Water Research, $2003,37(2)$ : $393-401$.

[61] Wang SR, Jin XC, Zhao HC et al. Effect of organic matter on the sorption of dissolved organic and inorganic phosphorus in lake sediments. Colloids and Surfaces, 2007, 297 : 154-162.

[62] Xie LQ, Xie P, Tang HJ. Enhancement of dissolved phosphorus release from sediment to lake water by Microcystis blooms - an enclosure experiment in a hyper-eutrophic, subtropical Chinese lake. Environmental Pollution, 2003,122 : 391-399. 